No 4069

Studia nad Autorytaryzmem i Totalitaryzmem 43, nr 2

Wrocław 2021

https://doi.org/10.19195/2300-7249.43.2.27

\author{
KRZYSZTOF NOWICKI \\ ORCID: 0000-0002-3692-2563 \\ Uniwersytet Wrocławski \\ krzysztof.nowicki@uwr.edu.pl
}

\title{
Niezależność sądu oraz niezawisłość sędziowska w sprawach karnych w okresie rządów autorytarnych i totalitarnych w Polsce
}

\author{
Słowa kluczowe: niezależność sądu, niezawisłość sędziowska, trójpodział władzy, pro- \\ ces karny. \\ THE INDEPENDENCE OF THE JUDICIARY AND JUDICIAL AUTONOMY \\ IN CRIMINAL CASES WITHIN THE PERIOD OF AUTHORITATIVE \\ AND TOTALITARIAN REGIMES IN POLAND
}

\begin{abstract}
At present, there is no doubt that a need exists to ensure the citizens' right to have a criminal case examined by an independent and unbiased court. For the proper functioning of the court-based administration of justice to be possible, the courts must have the attribute of independence and the judges must be autonomous. These issues are regulated in international treaties to which Poland is a party. The aim of this study is to describe the role of judiciary independence and judicial autonomy in criminal cases. In order to achieve these goals, considerations will be presented on the essence of such independence and autonomy, and a reference will be made to the way the authoritarian state functioned after the May coup in the Second Polish Republic, and the totalitarian state during the era of the Polish People's Republic.
\end{abstract}

Keywords: independence of the judiciary, judicial autonomy, tripartite division of powers, criminal proceedings. 


\section{Uwagi wstępne}

Aktualnie nie budzi wątpliwości konieczność zapewnienia obywatelom prawa do rozpoznania sprawy karnej przez niezależny i bezstronny sąd. Aby można było mówić o właściwym funkcjonowaniu sądowego wymiaru sprawiedliwości, sądy muszą mieć atrybut niezależności, zaś sędziowie muszą być niezawiśli. Zagadnienia te są uregulowane w aktach prawa międzynarodowego, których Polska jest stroną. Niniejsze opracowanie ma za zadanie opisać role niezależności sądów i niezawisłości sędziowskiej w sprawach karnych. Przedstawione zostaną standardy konwencyjne, konstytucyjne oraz zakres realizacji tych standardów w polskim ustawodawstwie. Dla osiągnięcia tych celów przedstawione zostaną rozważania dotyczące tytułowych zagadnień związanych z funkcjonowaniem struktur autorytarnych i totalitarnych w najnowszej historii Polski. W pierwszej części opracowania omówione zostaną zagadnienia związane $\mathrm{z}$ istotą i ujęciem historycznym niezależności sądów i niezawisłości sędziowskiej odwołującym się do funkcjonowania państwa autorytarnego po przewrocie majowym w II Rzeczypospolitej oraz totalitarnego w okresie PRL. W drugiej części opisane zostaną zagadnienia dotyczące realizacji tych standardów w aktualnym porządku prawnym oraz tego, czy zakres gwarancji mających zapewnić prawidłowe funkcjonowanie omawianych instytucji stanowi odpowiednią ochronę przed zagrożeniem funkcjonowania demokratycznego państwa prawa.

\section{1.}

Istotą rozważań związanych $\mathrm{z}$ omawianą problematyką jest oddzielenie sądów od władzy wykonawczej i ustawodawczej oraz ukształtowanie takiego funkcjonowania państwa, które zapewni wzajemne równoważenie się tych władz. Szczególne znaczenie ma zapewnienie skutecznej ochrony władzy sądowniczej przed możliwością ingerencji pozostałych władz, w szczególności wykonawczej. Przełomowe znaczenie dla ukształtowania się takiej idei miały publikacje Monteskiusza. Argumentując potrzebę rozdziału władz wskazywał on, że nie ma wolności, gdy w jednej i tej samej osobie lub jednym i tym samym ciele zespolona jest władza ustawodawcza i wykonawcza, ponadto

nie ma również wolności, jeżeli władza sądowa nie jest oddzielona od prawodawczej i wykonawczej. Gdyby była połączona z władzą prawodawczą, władza nad wolnością obywateli byłaby dowolną, sędzia byłby bowiem prawodawcą. Gdyby była połączona z władzą prawodawczą, sędzia mógłby mieć siłę ciemiężyciela ${ }^{1}$.

Wskazywał, że dla osiągnięcia możliwości nadużywania władzy, „trzeba aby przez naturalną grę rzeczy, władza powściągnęła władzę"

\footnotetext{
${ }^{1}$ Montesesquieu, O duchu praw, przeł. T. Boy-Żeleński, Warszawa 1957, s. 234.
}

2 Ibidem. 
Idea trójpodziału władzy znalazła swoje normatywne odbicie między innymi w Deklaracji praw człowieka i obywatela z 1789 roku, we francuskiej Konstytucji z 1791 roku oraz Konstytucji 3 maja, uchwalonej w tym samym roku. Niezależność sądów oraz niezawisłość sędziowska stanowią aktualnie istotny element regulacji międzynarodowych związanych z funkcjonowaniem wymiaru sprawiedliwości. Zgodnie z art. 14 ust. 1 Międzynarodowego paktu praw obywatelskich i politycznych ,każdy ma prawo do publicznego i sprawiedliwego rozpatrzenia sprawy przez właściwy, niezależny i bezstronny sąd, ustanowiony przez ustawę, przy orzekaniu co do zasadności oskarżenia przeciw niemu w sprawach karnych [...]". Podobnie prawo sprawiedliwego i publicznego procesu przed niezależnym i bezstronnym sądem zawiera regulacja art. 10 Powszechnej deklaracji praw człowieka, będącej pierwszym aktem prawnym regulującym kompleksowo prawa człowieka. Omawiane kwestie stanowią też przedmiot regulacji. Regulacje odwołujące się do prawa do rozpatrzenia jego sprawy w rozsądnym terminie przez niezawisły i bezstronny sąd znajdują się również w art. 6 ust. 1z Europejskiej konwencji o ochronie praw człowieka i podstawowych wolności oraz w art. 47 Karty praw podstawowych Unii Europejskiej.

Omawiane zagadnienia mają swoje normatywne ujęcie w Konstytucji RP. Zgodnie z regulacją art. 173 sądy są władzą odrębną i niezależną od innych. Ponadto każdy ma prawo do sprawiedliwego i jawnego rozpatrzenia sprawy bez nieuzasadnionej zwłoki przez właściwy, niezależny, bezstronny i niezawisły sąd (art. 45 ust. 1 Konstytucji RP). Natomiast zgodnie z regulacją art. 173 sądy i trybunały są odrębną władzą niezależną od innych. Zagadnienia dotyczące aktualnego stanu prawnego, zakresu funkcjonowania niezależności sądów i niezawisłości sędziów oraz konieczności stworzenia niezbędnych gwarancji w tym zakresie zastaną przedstawione w drugiej części niniejszego opracowania.

\section{2.}

Niniejsza część pracy będzie obejmowała zagadnienia związane z funkcjonowaniem sądownictwa w okresie II Rzeczypospolitej oraz w PRL. Opis ten zostanie ograniczony do wykazania, w jakim zakresie była realizowana niezależność sądów oraz niezawiłość sędziów w okresie funkcjonowania państwa autorytarnego oraz totalitarnego.

Po odzyskaniu niepodległości w Konstytucji z 1921 roku wprowadzono zasadzę trójpodziału władzy. Ustawa zasadnicza przyjęła, że sędziowie są w sprawowaniu swojego mandatu niezawiśli i podlegają tylko ustawom. Orzeczenia sądowe nie mogły być zmieniane, ani przez władzę ustawodawczą, ani przez władzę wykonawczą (art. 77).

$\mathrm{Na}$ istotną rolę niezawisłości sędziowskiej wskazano w sprawozdaniu ze 179. posiedzenia Sejmu Ustawodawczego z 1920 roku. Podkreślono, że nie może on 
wywierać żadnego wpływu na orzecznictwo sądowe ani interes państwa, ani interes poszczególnych grup czy warstw. Sędzia powinien być pod każdym względem niezależny. Ponadto wskazano, że wyrok sądowy może być zmieniony tylko w drodze instancji i nie może być stosowana żadna sprawiedliwość gabinetowa, gdzie orzeczenie sądowe może być zmienione bądź to przez ministra, bądź przez Prezesa Rady Ministrów, bądź nawet przez kogoś wyżej postawionego ${ }^{3}$. W literaturze, mimo kwestii spornych, wśród najbardziej istotnych ustrojowych gwarancji niezawisłości sędziowskiej wskazywano: właściwy system obsadzania stanowisk sędziowskich, pewność stanowiska, samorząd sędziowski, należyte uposażenie i odpowiednie warunki pracy, właściwy system nadzoru, niepołączalność z innym zatrudnieniem, apolityczność, odpowiednie przygotowanie ${ }^{4}$.

Po przewrocie majowym dokonano wielu działań mających na celu osłabienie niezależności sądów i niezawisłości sędziowskiej. W pierwszej kolejności osłabiono gwarancje konstytucyjne wykorzystując ustawodawstwo zwykłe. Zgodnie z art. 102 § 2 lit. a Rozporządzenia Prezydenta RP — Prawo o ustroju sądów powszechnych z 6 lutego 1928 roku (dalej: Prawo o ustroju sądów powszechnych) sędzia mógł być mianowany na inne stanowisko, przeniesiony na inne miejsce służbowe w wypadkach zmiany ustroju sądownictwa lub zniesienia danego sądu. Istniała nawet możliwość przeniesienia sędziego w stan spoczynku (art. 107 i 109). Natomiast zgodnie z regulacją art. 78 zd. 2 Konstytucji RP, sędziego można było usunąć lub przenieść w inne miejsce tylko wówczas, gdy było to wywołane zmianą $\mathrm{w}$ organizacji sądów postanowioną $\mathrm{w}$ drodze ustawy (wyr. - K.N.). Zgodnie z art. 2 § 2 Prawa o ustroju sądów powszechnych Prezydent RP miał prawo do ustalenia i zmiany okręgu i siedziby sądu w drodze rozporządzenia. Ponadto, także w drodze rozporządzenia, minister sprawiedliwości mógł w siedzibie sądu grodzkiego dla jednego lub kilku sądów grodzkich tworzyć stałe oddziały zamiejscowe sądów okręgowych (art. 3 Prawa o ustroju sądów powszechnych). Do tych oddziałów nie mianowano nowych sędziów, lecz przenoszono ich $\mathrm{z}$ danego sądu okręgowego ${ }^{5}$. Nowe przepisy pozwalały ponadto na usuwanie i przenoszenie sędziów do innej miejscowości lub w stan spoczynku „w interesie wymiaru sprawiedliwości lub powagi stanowiska sędziego" (art. 102 § 2 lit. c i 110 lit. c Prawa o ustroju sądów powszechnych). Przepisy nie

${ }^{3}$ Ze sprawozdania stenograficznego 179. posiedzenia Sejmu Ustawodawczego w 1920 roku, s. 32-33, za: M. Materiak-Pawłowska, Zawód sędziego w Polsce w latach 1918-1939, „Czasopismo Prawno-Historyczne" 63, 2011, z. 1, s. 75.

4 Por. G. Ławnikowicz, Idea niezawisłości sędziowskiej w porządku prawnym i myśli prawniczej Drugiej Rzeczypospolitej, Torun 2009, s. 342-377 i wskazana tam literatura.

5 M. Materiak-Pawłowska, Zawód sędziego..., s. 76. 
przewidywały gwarancji rzetelnej procedury dotyczącej takiego postępowania, w tym możliwości odwołania się od omawianej decyzji. W ówczesnej literaturze słusznie wskazywano na „bardzo rozciągły” zakres tych pojęć. Ponadto podnoszono, że

wprawdzie ma o tym decydować sąd w postaci Zgromadzenia Ogólnego, ale pytanie czy i Zgromadzenie Ogólne w tych wypadkach ma prawo sędziego usunąć lub przenieść, bo z ducha art. 78 konstytucji wynika, że usunięcie lub przeniesienie sędziego może nastąpić na mocy orzeczenia sądu karnego lub dyscyplinarnego za przestępstwo lub wykroczenie dyscyplinarne, nie zaś ze względów oportunistycznych ${ }^{6}$.

Trafnie wskazywano także na iluzoryczny charakter owej rękojmi sądowej związanej z koniecznością wydania orzeczenia przez Zgromadzenie Ogólne, gdyż może ono zostać zastąpione przez Kolegium Administracyjne.

Opierając się na tych regulacjach usunięto wielu niewygodnych dla ówczesnej władzy wykonawczej sędziów. Wśród nich byli Pierwszy Prezes Sądu Najwyższego Władysław Seyda, prezes Izby Karnej Sądu Najwyższego Aleksander Mogilnicki ${ }^{7}$ oraz sędziowie Sądu Najwyższego: W. Barański, M. Fedyński, L. Mendelsburg, F. Ochimowski. Nowelizacja Prawa o ustroju sądów powszechnych z dnia 4 marca 1929 roku uchyliła przepisy umożliwiające przenoszenie sędziów Sądu Najwyższego i sądów apelacyjnych bez ich zgody w inne miejsce lub w stan spoczynku w tak zwanym okresie organizacyjnym ${ }^{8}$. Niestety nastąpiło to już po usunięciu wielu niewygodnych sędziów.

Prawo o ustroju sądów powszechnych przewidywało ponadto system nadzoru nad sądami, który nie zapewniał sędziom poczucia bezpieczeństwa ze strony władz, mimo prawidłowego wykonywania przez nich swoich obowiązków. Powołano kolegia administracyjne z szerokimi uprawnieniami. W skład kolegiów wchodził prezes sądu i dwóch powołanych przez niego członków oraz dwóch członków wybieranych przez Zgromadzenie Ogólne. Prezes z osobami powołanymi przez siebie mieli więc $\mathrm{w}$ takim kolegium większość. Władze sądu miały liczne kompetencje umożliwiające wywieranie nacisku na sędziów w sytuacji, gdy wydawali oni orzeczenia zgodnie ze swoim sumieniem, ale takie które nie były zgodne z oczekiwaniem władzy wykonawczej. Należały do nich między

${ }^{6}$ J. Jamontt, Historia i krytyka rozporządzenia o ustroju sądów powszechnych, Warszawa 1928, s. 115.

7 A. Mogilnicki, Wspomnienia: spisane w Łodzi w latach 1949-1955, Warszawa 2008, s. 208, 218-230. Autor wskazuje, że przyczyna zwolnienia jego oraz W. Seydy była związana z uprawnieniem Sądu Najwyższego do wskazania trzech kandydatów na Generalnego Komisarza Wyborczego. Jednego z tych kandydatów miał w dalszym etapie wybrać Prezydent RP. Prezesi Sądu Najwyższego odmówili umieszczenia wśród trzech kandydatów przedstawienia osoby wskazanej przez Józefa Piłsudskiego. Kandydatem tym miał być ówczesny wiceminister S. Car, którego później prezydent i tak wybrał na Głównego Komisarza Wyborczego, wbrew przepisom prawa. A. Mogielnicki skorzystał z możliwości odwołania się od dekretu przenoszącego go w stan spoczynku do Najwyższego Trybunał Administracyjnego. Wniosek nie doczekał się rozpatrzenia przez 10 lat.

8 Dz.U. z 1930 r. Nr 5, poz. 43. 
innymi odsuwanie od wyrokowania przy delegowaniu do czynności administracyjnych, udzielanie urlopu wypoczynkowego w niedogodnym dla sędziego okresie, celowe przeciążenie sędziego pracą oraz niedopuszczanie do awansu. Jednocześnie mieli możliwość — w wyżej opisanym zakresie — „wynagradzać” posłusznych sędziów ${ }^{9}$.

Przepisy Prawa o ustroju sądów powszechnych dawały władzy wykonawczej możliwość istotnego oddziaływania na sędziów pokoju. Zgodnie z art. $2 \S 2$ tej regulacji minister sprawiedliwości miał prawo przenoszenia i usuwania sędziów pokoju poprzez rozporządzenia ustanawiające okręgi i siedziby sądów do ustalenia i zmiany okręgu sądu oraz umożliwiające ich znoszenie. Minister sprawiedliwości miał też prawo zwolnić sędziego pokoju przed upływem okresu, na który był powołany na podstawie uchwały zgromadzenia ogólnego właściwego sądu okręgowego lub zastępującego go kolegium administracyjnego (art. 206 § 2 Prawa o ustroju sądów powszechnych) ${ }^{10}$.

Kolejne bardzo istotne ograniczenie niezawisłości sędziowskiej wiązało się z rozporządzeniem Prezydenta Rzeczypospolitej z dnia 23 sierpnia 1932 roku $^{11}$. W regulacji tej znacznie ograniczono kompetencje zgromadzenia ogólnego na rzecz kolegium administracyjnego. Kolejne rozporządzenie Prezydenta Rzeczypospolitej z tego samego dnia upoważniało władzę mianującą do przenoszenia w okresie od 27 sierpnia do 31 października 1932 roku sędziów wszystkich sądów bez ich zgody do innego równorzędnego sądu lub w stan spoczynku ${ }^{12}$. Przepisy te pozwoliły na ponowne usunięcie niewygodnych dla władzy wykonawczej sędziów z pogwałceniem niezawisłości sędziowskiej ${ }^{13}$.

Należy też zwrócić uwagę na kwestię uposażeń sędziowskich na podstawie regulacji rozporządzenia Prezydenta Rzeczypospolitej z dnia 28 października 1933 roku, które przewidywało cztery grupy wynagrodzenia zasadniczego sędziów ${ }^{14}$. Szczegółowe zasady przyznawania sędziemu uposażenia właściwego dla danej grupy przewidywało natomiast rozporządzenie Rady Ministrów z dnia 19 grudnia 1933 roku $^{15}$. Sędziowie danego sądu mogli zostać przypisani do jednej z dwóch

9 M. Materiak-Pawłowska, Ustrój sądownictwa powszechnego w II Rzeczypospolitej, Poznań 2003, s. 277.

${ }^{10}$ Sędziowie pokoju mieli orzekać przy sądach grodzkich, nigdy jednak nie zostali na to stanowisko powołani.

11 Rozporządzenie Prezydenta Rzeczypospolitej z dnia 23 sierpnia 1932 roku zmieniające niektóre przepisy Prawa o ustroju sądów powszechnych (Dz.U. z 1932 r. Nr 73, poz. 661).

12 Rozporządzenie Prezydenta Rzeczpospolitej z dnia 23 sierpnia 1932 roku w sprawie upoważnienia władzy mianującej do przenoszenia sędziów w stan spoczynku i na inne miejsce służbowe (Dz.U. z 1932 r. Nr 73, poz. 663).

13 S. Włodyka, Organizacja wymiaru sprawiedliwości, [w:] Historia państwa i prawa Polski 1918-1939, cz. 2, red. F. Ryszka, Warszawa 1968, s. 26.

14 Rozporządzenie Prezydenta Rzeczypospolitej z dnia 19 grudnia 1933 roku (Dz.U. z 1933 r. Nr 786, poz. 665).

15 Rozporządzenie Rady Ministrów z dnia 10 grudnia 1933 roku o zasadach zaszeregowania do grup uposażenia sędziów w sądownictwie powszechnym i administracyjnym, prokuratorów, 
grup uposażenia przewidzianej dla danego sądu. Decyzję w tym zakresie podejmował minister sprawiedliwości. Przykładowo sędzia sądu okręgowego mógł otrzymać uposażenie zasadnicze z grupy IV lub III. Ponadto nowelizacja tego rozporządzenia z 1935 roku dała ministrowi sprawiedliwości, za zgodą Prezesa Rady Ministrów, możliwość wyjątkowego przyznawania sędziemu uposażenia grupy bezpośrednio wyżej od tej jaka mu przysługiwała z rozporządzenia ${ }^{16}$. Minister mógł więc decydować, którą z trzech grup uposażenia będzie sędzia danego sądu otrzymywał i w ten sposób miał możliwość nacisku na sędziego w zakresie jego orzecznictwa ${ }^{17}$.

Konstytucja kwietniowa z 1935 roku wprowadziła zasadę jednolitości władzy państwowej. Zgodnie z jej art. 3 wśród organów państwa pozostających pod zwierzchnictwem Prezydenta Rzeczypospolitej znajdywały się także sądy. W ten sposób zerwano z zasadą niezależności sądownictwa od innych władz. Zgodnie $\mathrm{z}$ art. 64 ust. 3 sędziowie w ramach sprawowanego urzędu sędziowskiego byli niezawiśli, niemniej w treści przepisu nie znalazł się już zapis ,podlegają tylko ustawie". Sędzia mógł zostać przeniesiony na inne miejsce urzędowania lub w stan spoczynku, gdy wywołane to było zmianą w organizacji sądów, postanowioną przez akt ustawodawczy (art. 66 ust. 2). Rozszerzono w ten sposób w stosunku do Konstytucji marcowej podstawę reorganizacji sądownictwa, pozwalającą na zawieszenie nieusuwalności i nieprzenaszalności sędziego z wyłączności ustawy także na dekret Prezydenta Rzeczypospolitej. Zawężono także zakres immunitetu sędziowskiego. Zgodnie z art. 67 Konstytucji z 1935 roku sędzia nie mógł być pociągnięty do odpowiedzialności karnej bez zezwolenia właściwego sądu dyscyplinarnego ani zatrzymany bez nakazu sądu, chyba że został schwytany na gorącym uczynku. Zniesiono natomiast zapis widniejący w art. 79 Konstytucji marcowej nakazujący, w przypadku zatrzymania na gorącym uczynku, niezwłoczne zwolnienie aresztowanego na żądanie sądu.

4.

Po drugiej wojnie światowej Polsce narzucony został ustrój, w którym nie było miejsca na niezależne sądy i niezawisłych sędziów. Sądownictwo, obok takich struktur jak wojsko czy policja, miało pomagać w utrzymaniu władzy oraz likwidacji przeciwników politycznych. Jako przykład rozumowania osób prowadzących otwarcie tę politykę można podać program przedstawiony przez Władysława Gomułkę, który w czasie narady PPR w Lublinie 14 listopada 1944 roku wskazał, że

oraz asesorów i aplikantów sądowych, tudzież i dodatkach lokalnych i funkcyjnych (Dz.U. z 1933 r. Nr 102, poz. 782).

16 Rozporządzenie Rady Ministrów z dnia 6 lutego 1935 roku (Dz.U. z 1935 r. Nr 10, poz. 51).

17 Por. na przykład M. Materiak-Pawłowska, Zawód sędziego..., s. 96. 
trzeba obsadzić wszystkie kierownicze stanowiska w aparacie administracyjnym państwa, jak też wszystkie ogniwa siły zbrojnej narodu, również i sądownictwa, ludźmi którzy wszystkimi nici związani są z obozem demokracji polskiej, którzy myślą takimi kategoriami, jakimi myśli rząd demokratyczny ${ }^{18}$.

Pierwsze regulacje ustrojowe dotyczące funkcjonowania wymiaru sprawiedliwości zmierzały do ukształtowania przepisów, dzięki którym będzie możliwe odpowiednie dla władzy wykonawczej kształtowanie polityki kadrowej wśród sędziów. Dekretem PKWN z 27 grudnia 1944 roku zrównano pozycję sędziów z pozycją urzędników państwowych ${ }^{19}$. Zgodnie z art. 6 ust. 1 tego dekretu minister sprawiedliwości posiadał ponadto prawo do zmiany stanowiska służbowego sędziego, zwolnienia go lub przeniesienia w stan spoczynku bez konieczności wystąpienia okoliczności przewidzianych w Prawie o ustroju sądów powszechnych.

Z późniejszych wypowiedzi przedstawicieli władzy wykonawczej wynikało, że w PRL nie ma miejsca na niezależność sądownictwa i niezawisłość sędziów w rozumieniu wynikającym z trójpodziału władzy. Tworzono własne definicje niezawisłości sędziowskiej na potrzeby funkcjonowania państwa totalitarnego. Wiceminister T. Rek w 1951 roku napisał, że

sędzia nie ma i nie może posiadać jakiejś niezawisłości abstrakcyjnej [...]. Sądownictwo Polski Ludowej — organ władzy państwowej, składowa części aparatu ucisku w stosunku do wroga klasowego - jest organem dyktatury proletariatu i zadaniem tego organu jest pełny współudział wraz ze wszystkimi innymi organami władzy w realizacji tej dyktatury. [...] zasada niezawisłości sędziowskiej stanowi [...], że sędziowie nie mogą działać samowolnie, nie mogą sami tworzyć norm prawnych, lecz obowiązani są postępować zgodnie z prawem, zgodnie z wytycznymi partii i polityką Rządu ${ }^{20}$.

Istotne znaczenie dla omawianych zagadnień miał dekret z 22 stycznia 1946 roku o wyjątkowym dopuszczeniu do obejmowania stanowisk sędziowskich, prokuratorskich, notarialnych oraz wpisywania na listę adwokatów, który wprowadził do prawa o ustroju sądów powszechnych pojęcie rękojmi ${ }^{21}$. Zgodnie z art. 4 dekretu poszczególne osoby miały dawać rękojmie należytego wykonywania obowiązków sędziowskich lub prokuratorskich ze względu na „kwalifikacje osobiste, działalność naukową, zawodową, społeczną lub polityczną i dostateczną znajomość prawa [...]". Jednocześnie ten sam przepis dawał ministrowi sprawiedliwości uprawnienie w okresie pięciu lat od wejścia w życie dekretu do dopuszczania do zawodu sędziego osób niespełniających wymogu ukończenia uniwersyteckich studiów prawniczych, odbycia aplikacji i złożenia egzaminu sędziowskiego oraz przesłużenia określonej liczby lat na stanowiskach sędziowskich i prokuratorskich.

18 W. Gomułka, Artykuły i przemówienia, Warszawa 1962. Cyt. za: A. Rzepiński, Sąownictwo w PRL, Warszawa 1989, s. 27.

19 Dekret PKWN z 27 grudnia 1944 roku o tymczasowym unormowaniu stosunku służbowego i zaszeregowaniu funkcjonariuszy, Dz.U. z 1944 r. Nr 16, poz. 89.

20 Cyt. za: J. Szarycz, Sędziowie i sądy w Polsce w latach 1918-1988, Warszawa 1988, s. 328.

21 Dz.U. z 1946 r. Nr 54, poz. 54. 
Konstytucja z 1952 roku przewidywała formalną niezawisłość sędziów, natomiast gwarancje niezawisłego orzekania miały charakter fasadowy. Było wiele przepisów, które miały na celu podporządkowanie sędziów organom władzy. W PRL nie respektowano międzynarodowej zasady wyłącznej kompetencji sądów do rozstrzygania sporów prawnych. Powielono w ten sposób tendencje obecne w innych krajach bloku socjalistycznego i korzystano z orzecznictwa organów o charakterze społeczno-administracyjnym ${ }^{22}$. W sprawach o wykroczenia orzekały kolegia do spraw wykroczeń. Istniało również wiele innych podobnych organów mających uprawnienia orzecznicze, na przykład komisje rozjemcze i odwoławcze do spraw pracy, komisje do spraw szkód górniczych, Państwowy Arbitraż Gospodarczy, Komisja Odwoławcza przy Urzędzie Patentowym oraz izby morskie.

W okresie Polski Ludowej dążono do jak największego uzależnienia sędziów od władzy wykonawczej i kierownictwa administracji sądowej. Działania takie zaczynały się już na etapie aplikacji sądowej i zmierzały do wybrania „odpowiedniego" kandydata. Niewątpliwie miała w tym pomóc między innymi opisana powyżej instytucja rękojmi. Od kandydatów na sędziów wymagano przynależności do partii komunistycznej. Jak wskazywał sędzia Sądu Najwyższego S. Rudnicki, podejmowane były celowe działania zmierzające

do zachwiania równowagi między poszczególnymi wymaganiami stawianymi kandydatom do zawodu wykonywania sędziowskiego, przez przyznawanie decydującego znaczenia przynależności partyjnej, często także deklarowanemu światopoglądowi materialistycznemu kandydata. Wytworzyła się tzw. grupa sędziów dyspozycyjnych. Osoby, które nie chciały się poddać tendencjom, albo w ogóle nie trafiały do wymiaru sprawiedliwości, albo szybko z niego odchodziły ${ }^{23}$.

Z danych statystycznych przedstawionych przez A. Rzepińskiego wynika, że w okresie PRL im wyższy był szczebel sądownictwa, tym więcej sędziów należało do $\mathrm{PZPR}^{24}$. Dyspozycyjność sędziów kształtowano także przy pomocy kar wymierzanych za niepodporządkowanie się poleceniom wydanym przez prezesa sądu. Wśród tych kar i elementów nacisku można wymienić: odebranie sędziemu orzekania w powierzonej mu sprawie, wstrzymanie należnego awansu, nadmierne obciążenie pracą w porównaniu do innych sędziów, przesunięcie sędziego do innego wydziału czy nawet odległego sądu ${ }^{25}$.

Należy jeszcze zwrócić uwagę na dwie kwestie mające istotny wpływ na omawiane zagadnienia związane z Sądem Najwyższym. Pierwsza z nich odnosi się do wytycznych Sądu Najwyższego. Stanowiły one sposób oddziaływania na sądy zgodnie z oczekiwaniami partii, ministerstwa sprawiedliwości, MSW i innych instytucji władzy wykonawczej. Wytyczne Sądu Najwyższego w zakresie

${ }^{22}$ L. Garlicki, Aktualne tendencje ustroju sądownictwa w europejskich państwach socjalistycznych, „Państwo i Prawo” 1974, nr 11, s. 43-44.

23 Cyt. za: J. Szarycz, op. cit., s. 334.

24 A. Rzepiński, op. cit., s. 69-70.

25 Szerzej zob. ibidem, s. 66-73. 
wykładni prawa i praktyki sądowej wiązały wszystkie sądy (art. 23 ust. 1 ustawy o Sądzie Najwyższym z 1984 roku). Jednocześnie sprzeczność orzeczenia sądowego z treścią wytycznych Sądu Najwyższego mogła być samoistną podstawą uchylenia tego orzeczenia (art. 13 ust. 3, art. 17 ustawy o Sądzie Najwyższym z 1984 roku). Wytyczne dotyczyły zdarzeń przyszłych, nie były związane z konkretną sprawą karną (postępowaniem). Słusznie wskazano w literaturze, że miały one $\mathrm{w}$ istocie charakter przepisów prawnych, dodając, że wniosek uprawnionego podmiotu w zakresie wydania wytycznych musiał być co najmniej akceptowany przez partię ${ }^{26}$. Drugim zagadnieniem związanym z Sądem Najwyższym jest jego kadencyjność. Po zakończeniu pięcioletniej kadencji sędzia, który był nieposłuszny oczekiwaniom władzy wykonawczej, miał realne zagrożenie niepowołania na kolejną kadencję. Nie było możliwości zaskarżenia lub skutecznego kwestionowania takiej decyzji. Niewątpliwie omawiane rozwiązanie ustawowe stanowiło istotne naruszenie gwarancji związanych z niezawisłością sędziowską.

Przedstawione zagadnienia dotyczące okresów, kiedy w Polsce przejawiały się rządy autorytarne lub totalitarne pozwalają na wyciągnięcie istotnych wniosków dotyczących konieczności odpowiedniego ukształtowania aktualnie obowiązujących rozwiązań. Zapewnienie funkcjonowania zasady niezależności sądów oraz niezawisłości sędziowskiej oznacza nie tylko konieczność przyjęcia takich rozwiązań w przepisach prawa. Uregulowanie trójpodziału władzy oraz niezawisłości sędziowskiej w przepisach najwyższej rangi w danym kraju nie daje gwarancji spełnienia celów tych regulacji. Niezbędne jest takie ukształtowanie odpowiednich gwarancji, które pozwoli na realizację tych zasad procesowych. Analiza funkcjonowania omawianych zagadnień najnowszej historii Polski wskazuje na zagrożenia jakie mogą wiązać się z niedocenianiem roli wskazanych gwarancji. Jednocześnie należy pamiętać o korzyściach, jakie w związku z ograniczeniem niezależności sądów i niezawisłości sędziowskiej mają osoby sprawujące przede wszystkim władzę wykonawczą, zarówno w państwie autorytarnym, jak i totalitarnym. Im większe uprawnienia w takie sytuacji ma władza wykonawcza, tym większe jest zagrożenie dla swobód obywatelskich.

Kształtując po 1989 roku ustrój państwa polskiego starano się przyjąć takie rozwiązania, które zapewnią realne gwarancje niezależności sądów oraz niezawisłości sędziowskiej. W pierwszej kolejności przywrócono zasadę podziału władzy oraz ustanowiono konstytucyjnie Krajową Radę Sądownictwa składającą się z przedstawicieli władzy ustawodawczej, wykonawczej i sądowniczej. Organ ten ma wpływ między innymi na ocenę kandydatów na sędziów oraz ich awanse. Wprowadzono zasadę powoływania sędziów przez Prezydenta RP oraz zasadę nieusuwalności sędziów z wyjątkiem ściśle określonych przypadków. Ustanowiono zakaz przynależności sędziego do partii politycznych i związków zawodowych. Znacznie rozszerzono uprawnienia samorządu sędziowskiego, któremu

26 Ibidem, s. 74. 
dano uprawnienia do współdecydowania o obsadzaniu stanowisk członków kolegium sądu oraz prezesów sądu (bezpośrednio lub pośrednio). Ponadto wprowadzono kadencyjność prezesów sądów. Wśród najbardziej istotnych zmian, które nastąpiły po okresie państwa totalitarnego, należy też wskazać uzależnienie wysokości wynagrodzenia sędziów jedynie od rodzaju sądu, wysługi lat oraz sprawowanej funkcji. Wprowadzono też między innymi dwie bardzo istotne zmiany dotyczące funkcjonowania Sądu Najwyższego: zniesiono kadencyjność sędziów orzekających w tym sądzie oraz zrezygnowano z wymogu rękojmi należytego wykonywania obowiązków sędziego, obowiązującej wcześniej przy powoływaniu i odwoływaniu sędziów.

\section{Bibliografia}

Garlicki L., Aktualne tendencje ustroju sadownictwa w europejskich państwach socjalistycznych, „Państwo i Prawo” 1974, nr 11.

Gomułka W., Artykuty i przemówienia, Warszawa 1962.

Jamontt J., Historia i krytyka rozporządzenia o ustroju sąów powszechnych, Warszawa 1928.

Ławnikowicz G., Idea niezawistości sędziowskiej w porządku prawnym i myśli prawniczej Drugiej Rzeczypospolitej, Torun 2009.

Materiak-Pawłowska M., Ustrój sądownictwa powszechnego w II Rzeczypospolitej, Poznań 2003.

Materiak-Pawłowska M., Zawód sędziego w Polsce w latach 1918-1939, „Czasopismo Prawno-Historyczne" 63, 2011, z. 1.

Mogilnicki A., Wspomnienia: spisane w Łodzi w latach 1949-1955, Warszawa 2008.

Montesesquieu, O duchu praw, przeł. T. Boy-Żeleński, Warszawa 1957.

Rzepiński A., Sąownictwo w PRL, Warszawa 1989.

Szarycz J., Sędziowie i sady w Polsce w latach 1918-1988, Warszawa 1988.

Włodyka S., Organizacja wymiaru sprawiedliwości, [w:] Historia państwa i prawa Polski 1918-1939, cz. 2, red. F. Ryszka, Warszawa 1968. 